\title{
PATTERNS OF FEDERALISM IN EU MACROECONOMIC POLICY
}

\author{
JOSEFIN JENNERHEIM*
}

\begin{abstract}
The purpose of the article is to discern the pattern of federalism in EU macroeconomic governance and seek explanations for the strengthening of the framework in this regard. The article operates in a constitutional perspective, adopting a multidimensional approach in order to fulfil the purpose. These approaches have in common that they regard issues of legal power, resulting in a structure of five critical axes related to the nature of the Union's competence in macroeconomic governance. More precisely, within these dimensions, the nature of the exercise of legal power, its constitutionality and its implications for the allocation of power between the Union and the Member States are explicated. This thematized presentation is sought to make effective the uneartbing of a pattern of federalism. Lastly follows a discussion on the direction of the EU institutional practices in macroeconomic governance and the underlying causes for this development. In addition to drawing on the conclusions on the questions basing the article, this discussion will also feature thoughts on the recent battle between the Commission and the Italian government as regards the latter's national budget.
\end{abstract}

\section{INTRODUCTION}

Over a decade ago, the renowned EU scholar Gráinne de Búrca put forward the following lengthy proposal, of which I will reproduce in full by reason of its brilliance:

An interesting research question might therefore be to examine the 'pattern(s) of federalism' in the EU to date, and to try to provide a careful, systematic and considered account of why, despite the repeated concerns articulated by certain governments, both national and regional, about the creeping competences of the EU and the growth of its central powers at the expense of statal and regional capacity, the trend - both in terms of the constitutional/ treaty framework through its many amendments, culminating in the current constitutional treaty, as well as in terms of the practice of its institutions - has been mostly in one direction so far. ${ }^{1}$

De Búrca's inquiry was proposed prior to the global and European economic crises but might be the most urgent in post-crisis (potentially, pre-new-crisis ${ }^{2}$ ) times. The institutional measures adopted in response to the crisis have been claimed to counter the principle of the

\footnotetext{
* LL.M from Lund University (2019), trainee at Mannheimer Swartling's EU and Competition law practice group (Brussels). The article builds on the author's master thesis carried out at Lund University. The author would like to thank professor Xavier Groussot for the help and valuable comments, and the professors at KU Leuven for inspiring lectures on the subject matter of the article. All opinions belong to the author and do not purport to represent those of the mentioned associations. Contact: jennerheim@gmail.com.

${ }^{1}$ Gráinne De Búrca, 'Limiting EU powers', (2005) European Constitutional Law Review 12, 92, 98.

2 International Monetary Fund, 'A Decade after the Global Financial Crisis: Are We Safer?’ (Global Financial Stability Report October 2018), <https://www.imf.org/en/Publications/GFSR/Issues/2018/09/25/GlobalFinancial-Stability-Report-October-2018\#Front\%20Matter> accessed 9 April 2019.
} 
rule of law ${ }^{3}$, have adverse effects on legal certainty ${ }^{4}$ and been described as exuberating elements of authoritarianism ${ }^{5}$. This enumeration includes only some of the concerns voiced by contemporary legal scholars. The description of these measures ranges from 'nasty overregulation' to being necessary to prevent further crises in the euro area ${ }^{7}$, which of course do not have to be mutually exclusive. In any case, one can conclude that the constitutional set-up pre-crisis versus post-crisis has been changed dramatically.

The constitutional implications of the economic crisis has been analysed, by Alicia Hinarejos $^{8}$, as well as Karlo Tuori and Klaus Tuori ${ }^{9}$, to name a few. In this article, I will focus the magnifying glass on a specific part of the Union's economic policy - namely, macroeconomic policy. Accordingly, taking up de Búrcas invitation, this article aims at answering the questions posed by de Búrca in the context of the macroeconomic framework in the EU legal order.

As pointedly put by Guillaume Tusseau, federalism is a complex concept, and undoubtedly, various forms of federalism exists in different legal orders. In addition, the general concept of federalism cannot be considered a neutral term, and therefore, the various connotations of federalism may cloud the legal analysis if one adhere to such an ambiguous concept. ${ }^{10}$ For these reasons, the foundation of my exploration of the patterns of federalism in EU macroeconomic framework is Tusseau's theory on power-conferring norms which he adopted for the question of whether the EU is a federal order. So, on the basis of Tusseau's theory, I will answer the following questions in this article: (i) how the Union is exercising/has exercised legal competence in the context of the macroeconomic framework, and (ii) how this exercise affects the allocation of legal power between the Member States and the Union. By answering these questions, my intention is to provide a part of the pattern considered by de Búrca.

Additionally, I will test de Búrca's depiction of consistently increasing centralization of legal power in the EU legal order. As I will argue, I find that there has indeed been a theoretical centralization, which however has not materialized in practice. The reasons therefore will be discussed within the frame of my conclusions on the exercise of legal power in macroeconomic policy and its implications for the allocation of legal power in the EU legal order, in consideration of the fact that there are many reasons that centralization has developed in the described manner.

\footnotetext{
${ }^{3}$ Claire Kilpatrick, 'On the Rule of Law and Economic Emergency: The Degradation of Basic Legal Values in Europe’s Bailouts’ (2015) Oxford Journal of Legal Studies 35(2), 325, 325 ff.

4 Pablo Martín Rodriguez, 'A Missing Piece of European Emergency Law: Legal Certainty and Individuals' Expectations in the EU Response to the Crisis' (2016) European Constitutional Law Review 12, 265, 265293.

5 Alexander Somek, 'Delegation and Authority: Authoritarian Liberalism Today' (2015) European Law Journal 21(3), 340, 357 ff.

6 ibid, 345.

${ }^{7}$ This is naturally the position of the Union legislator, see for example: European Commission, 'EU Economic governance "Six-Pack" enters into force' (Press Release) MEMO/11/898.

${ }^{8}$ Alicia Hinarejos, The Euro Area Crisis in Constitutional Perspective (Oxford Scholarship Online 2015).

${ }^{9}$ Kaarlo Tuori and Klaus Tuori, The Eurozone Crisis - A constitutional analysis (Cambridge University Press 2014).

${ }^{10}$ Guillaume Tusseau, 'Theoretical Deflation: The EU Order of Competences and Power-Conferring Norms Theory' in Loic Azoulai (ed), The Question of Competence in the European Union (Oxford Scholarship Online 2014) $40 \mathrm{ff}$.
} 
Naturally, many of the EU policy areas and thereto corresponding secondary legislation will affect macroeconomic issues in the Union in its different dimensions. All of the provisions that have an effect on the macroeconomic choices of the Member States will not be provided for in this article. The stem of the framework under consideration in this article is Regulation 1176/2011 ('the MIP-regulation') ${ }^{11}$, which was adopted as a part of the six-pack legislation as a response to the economic crisis ${ }^{12}$. This regulation and its relation to other instruments of relevance will be briefly described below.

\section{CONFERRAL VERSUS CONSTITUTIONALISATION IN A FEDERAL ORDER OF COMPETENCES}

Not only is the discern of a pattern of federalism a difficult task in itself, but within this task, there is a web of concepts that have or could have a bearing on the outcome of the task. All these threads cannot be entertained in this article, for reasons of both sanity and space. Instead, the below concepts that I have chosen to consider all regard the issue of legal power of the EU.

\subsection{CONFERRAL VERSUS CONSTITUTIONALISATION}

There are two traction forces in the development of federalism in the EU. To simplify, this relationship can be described as follows. Conferral, on the one hand, aims to ensure that the legal power retains in the hands of the Member States, by limiting the Union's action to the competences conferred on it by the Member States in the Treaties. ${ }^{13}$ Constitutionalisation, on the other hand, is the process of which the EU constitution is regarded to mainly be shaped by other constitutional actors than the Member States, namely the EU institutions. ${ }^{14}$ The principle of conferral as set out in article 5(2) TFEU entails that 'the objectives [of the Union] are functional to competencies, and not the other way around. ${ }^{15}$ Thus, the Union institutions cannot act outside of their competences on the ground that the action attains a Union objective.

De Búrca advocates that although the principle of conferral is an 'important starting point' for addressing the exercise and division of power, 'the actual nature of the federal system in question emerges through the institutional practice over time. ${ }^{16}$ In light thereof, my intention is not to provide a normative review on the topics discussed the article, and so, I will not set conferral as an ideal, neither to dismiss it on the grounds of the process of

\footnotetext{
${ }^{11}$ Regulation (EU) No 1176/2011 of the European Parliament and of the Council of 16 November 2011 on the prevention and correction of macroeconomic imbalances [2011] OJ L306/25 (The MIP-regulation).

12 European Commission, MEMO/11/898 (n 7).

13 Articles 5(1) and 5(2) TFEU; Barbara Guastaferro, 'The European Union as a Staatenverbund? The Endorsement of the Principle of Conferral in the Treaty of Lisbon' in Martin Trybus and Luca Rubini (eds), The Treaty of Lisbon and the Future of European Law and Policy (Cheltenham, 2012: Edward Elgar) 123; Stephen Weatherill, 'The Constitutional Context of (Ever-Wider) Policy-Making' in Erik Jones, Anand Menon and Stephen Weatherill (eds), The Oxford Handbook of the European Union (Oxford Scholarship Online 2012) 571; Inge Govaere, To Give or to Grab: The Principle of Full, Crippled and Split Conferral of Powers Post-Lisbon (College of Europe: Research Papers in Law 04/16 2016) 2.

${ }_{14}$ Tuori and Tuori (n 9) $3 \mathrm{ff}$.

15 Guastaferro (n 13) 127.

16 De Búrca (n 1) 94.
} 
constitutionalisation. Rather, both of these concepts will be kept in mind as I analyse the exercise of EU legal power in macroeconomic policy.

As the Member States have conferred competence to the Union, the principle of conferral constitutionally limits the use of those competences. Another pair of conceptual lenses is that of delegation, in that the Member States have delegated powers to the Union. On this note, Alexander Somek has created a theory about trust and delegation of power. According to Somek, a delegation of power presupposes trust from the delegator towards the delegated. Overstepping a mandate will result in either 'the normative reassertion of an expectation ('you should have') or the cognitive adjustment to a new situation ('so, this is what you had to do')'. The inherent problem with the presumption of trust is therefore, even as it builds on a legal mandate, that the delegator always can derive a normative confirmation ('you should or should not have') after the fact. Somek states that in legal systems such as these, 'the reversal in the direction of control is built into the relationship'. The Member States must therefore trust the Union as it has conferred power on it, but the control of the exercise of power can only happen after the exercise has taken place. Somek calls this fault in the system of delegation a 'modal indifference of trust'. Somek maintains that the only efficient way to deal with this issue is by political bodies rather than the judiciary through democratic control. In this regard, he argues that political bodies are able to redefine the relationship to the delegated whilst the judicial bodies are limited to address the normative mode (you should or should not have done so). ${ }^{17}$ A system wherein the people have no democratic outlet result in a 'trust trap', in which they cannot assert their normative expectations and thereby believe they must accept their fate. ${ }^{18}$

\section{2}

LEGAL POWER AND POWER-CONFERRING NORMS

When one is exploring the constitutional relationship between the legal power of the Member States and those of the Union, there is a need for a concept of legal power. In Neil Maccormick's theory of legal power, he argues that power give rise to reasons for action or inaction that would, without it, not have existed. Legal power is further explained as the legally conferred ability to affect or prevent change in another person's legal position without the consent or dissent of that person. As regards the distinction between normative power and power-in-fact, especially political power, Maccormick argues that, although they should be distinguished, these powers are often interdependent; the legal order and political power go hand in hand. The legal order and legal power are dependent on legitimacy, consequently, if the legal actor, having legal power, cannot exercise its power-in-fact, it will erode the legitimacy of the legal order. ${ }^{19}$

In light of the multifaceted playing field that is the EU legal order, as set out above, there is a need for a tool to outline the constitutional relationships of the legal orders contained in the EU legal order, namely that of the Member States and that of the EU. Such a tool is found in Tusseau's theory on power-conferring norms. Tusseau's 'proposed concept' of power-conferring norms includes four elements. The first concerns the actor

\footnotetext{
17 Somek (n 5) 351.

18 ibid $352 \mathrm{ff}$.

${ }^{19}$ Neil MacCormick, 'Powers and Power-Conferring Norms' in Stanley L. Paulson (ed), Normativity and Norms: Critical Perspectives on Kelsian Themes (Oxford University Press 1999) 493 ff.
} 
empowered to produce legal norms. The second is that of the action by means of which that actor can produce norms. Thirdly, the 'range of application' of the power-conferring norm determines the 'area of reality' in which the actor is empowered to act, for example in regard to territorial, temporal material and/or personal criteria. The fourth element is the 'range of regulation' which refers to the normative meaning of the production of the power-conferring norms, namely to the type of norm that is empowered and its level in the normative hierarchy. ${ }^{20}$

Additionally, Tusseau identifies types of relationships between power-conferring norms in the EU legal order. The relationship is twofold - namely that of the 'principle of hierarchy' and the 'coordination of power-conferring norms'. The former refers to the vertical relationship between the power-conferring norms produced by the various actors, and the nature of that hiearchization. Conversely, the latter refers to the horizontal relationship between power-conferring norms in relation to their respective ranges of application. $^{21}$

Tusseau's theory, albeit reiterated here in a scaled-down version, provides useful tools in outlining the nature of the legal power conferred on the Union and its relationship to the legal power of the Member States, thus in turn for mapping the pattern of federalism created by the Union's exercise of power in macroeconomic policy.

\section{CRITICAL AXES OF MACROECONOMIC COMPETENCE PRACTICE}

The rationale of this article, as explained above, is that the examination of the Union's exercise of legal power and its allocation in the EU legal order will produce a basis for discussing the structure of federalism as regards the Union's macroeconomic policy. There is naturally many aspects of such an exercise, all of which will not be accounted for in this article. Perhaps most pertinently, it will not consider the roles of the principles of subsidiarity and proportionality.

The following five dimensions will be considered; (i) the instruments used in macroeconomic policy and their respective ranges of regulation and application, (ii) the use of enhanced cooperation, (iii) the implications of enforcement mechanisms in the framework, (iv) the constitutional actors empowered by the legal instruments, and (v) the objectives of macroeconomic policy. Hypothetically or factually, the intersection of all these axes will represent the relationship between the Union's and the Member States' legal power that makes up the federal pattern sought after.

\subsection{THE BASICS AND UNDERLYING PRINCIPLES OF ECONOMIC POLICY COMPETENCE}

The original set-up of the economic constitution included a 'decentralised' fiscal policy, in which the Union lacked a 'centralized fiscal policy function and ... centralized fiscal capacity' within a monetary Union. ${ }^{22}$ Prior to the economic crisis, the EU economic governance focused on fiscal policy rules, primarily through the Sustainability and Growth Pact ('SGP')

\footnotetext{
20 Tusseau (n 10) 46; see also ibid 46 ff.

21 ibid 54 ff; see also ibid 55 ff.

${ }^{22}$ European Commission, 'A blueprint for a deep and genuine economic and monetary union Launching a European Debate’ COM (2012) 777 final, 2.
} 
(as it was designed prior to the six and two-pack legislation). The economic distress of the crisis has been explained by the European Commission ('Commission') to be partially caused by the non-compliance of the rules of the SGP. The Commission has argued that 'features of the original institutional setup of [the Economic and Monetary Union], in particular the lack of a tool to address systematically macroeconomic imbalances' was a vulnerability in the old system. ${ }^{23}$ However, the strengthening of EU economic governance post-crisis has been described as a challenge to the underlying principle of fiscal autonomy of the Member States. ${ }^{24}$

As per article 2(3) TFEU, '[t]he Member States shall coordinate their economic and employment policies within arrangements as determined by this Treaty, which the Union shall have competence to provide'. Further, article 5(1) TFEU reads:

The Member States shall coordinate their economic policies within the Union. To this end, the Council shall adopt measures, in particular broad guidelines for these policies. Specific provisions shall apply to those Member States whose currency is the euro.

Notably, these provisions do not specify whether the Union's competence in economic policy is shared or exclusive, or in general how it relates to the competence of the Member States. The ambiguity has prompted varying scholarly interpretations of the nature of this competence. In one corner, there is the view that economic policy is attributed the area of shared competences as it is a residual competence in accordance with article 4(1) TFEU ${ }^{25}{ }^{26}$ Additionally, there are those who argue that competence in economic policy exists on a spectrum between shared competence and the category of supporting, coordinating and supplementary (article 2(5) TFEU). ${ }^{27}$ This approach is somewhat similar to that of Roland Bieber who opposes the attribution of coordinating competence to shared competences, instead considering that the Union's competence in economic policy is a 'sui generis', dividing the competence in relation to each type of measure. ${ }^{28}$

Lastly, the terms 'providing arrangements' and 'coordinate' in the Treaty provisions have also sparked a debate on its implications for the nature of competence in economic policy, in which some scholars argue on the basis of this language, that the Union cannot pursue its own economic policy nor decide on the policy choices of the Member States. ${ }^{29}$

\footnotetext{
23 ibid.

24 Tuori and Tuori (n 9) 188 ff.

25 Article 4(1) TFEU stipulates that 'the Union shall share competence with the Member States where the Treaties confer on it a competence which does not relate to the areas referred to in Articles 3 and 6', whereas economic policy is listed in article 5 TFEU.

26 Allan Rosas and Lorna Armati, EU Constitutional Law - an introduction (3rd edn, Hart Publishing 2018) 23-

25; Jean-Claude Piris, The Lisbon Treaty: a legal and political analysis (Cambridge University Press 2010) 77.

27 Robert Schütze, European Union Law (Cambridge University Press 2015) 242.

${ }^{28}$ Roland Bieber, 'Allocation of Economic Policy Competences in the EU' in Loïc Azoulai (ed), The Question of Competence in the European Union (Oxford Scholarship Online 2014) $89 \mathrm{ff}$.

${ }^{29}$ Hinarejos (n 8) 73 ff; Koen Lenaerts, 'EMU and the EU's constitutional framework' (2014) European Law Review 39(6) 753, 766.
} 
In the first axis of macroeconomic competence, the instruments used in macroeconomic policy and their respective ranges of regulation and application can be said to make up the scope of the macroeconomic framework. In other words, this scope should answer what legal production the Union can create on the basis of the macroeconomic competence conferred on it.

\section{2[a] The MIP-regulation and related instruments}

As such, macroeconomic policy is not expressly mentioned in the Treaties. However, the MIP-regulation is based on article 121(6) TFEU. Article 121(6) TFEU provides for detailing (through regulations) the multilateral surveillance procedure, which entails surveillance and assessments of economic developments in the Member States and enabling consistency of the economic policies with the Broad Economic Policy Guidelines ('BEPG's') adopted in regard to each Member State. ${ }^{30}$

The preamble of the MIP-regulation recognizes that 'supplement' to the multilateral surveillance procedure with 'specific rules' for detecting, preventing and correcting macroeconomic imbalances is appropriate. ${ }^{31}$ The MIP-regulation is complemented by Regulation 1174/2011 ('the Enforcement-regulation') ${ }^{32}$ which provides for financial sanctions for the Eurozone States following non-compliance with parts of the MIPregulation.

The procedure for detecting and preventing imbalances is called the macroeconomic imbalance procedure ('MIP'). The regulation defines a macroeconomic imbalance as:

[...] any trend giving rise to macroeconomic developments which are adversely affecting, or have the potential adversely to affect, the proper functioning of the economy of a Member State or of the economic and monetary union, or of the Union as a whole..$^{33}$

Clearly, the definition of macroeconomic imbalances is very broad. The detection of imbalances is facilitated by the so-called scoreboard which is created by the Commission and is based on numerous numerical fiscal benchmarks. ${ }^{34}$ The Commission produces reports on all Member States on the basis of the scoreboard ${ }^{35}$, which may prompt the Commission to undertake an in-depth review of Member States at potential risk ${ }^{36}$. On the basis of this review, the Commission can conclude that the Member State in question is experiencing either no imbalance, an imbalance or an excessive imbalance. Where an (non-excessive) imbalance is detected, the Council of the European Union ('Council') may address

\footnotetext{
30 Articles 121(6), 121(3) and 121(2) TFEU.

31 Regulation (EU) No 1176/2011 (n 11), para 9.

${ }^{32}$ Regulation (EU) No 1174/2011 of the European Parliament and of the Council of 16 November 2011 on enforcement measures to correct excessive macroeconomic imbalances in the euro area.

${ }^{33}$ Regulation (EU) No 1176/2011 (n 11) art. 2(1).

34 ibid art. 4.

35 ibid art. 3(2).

36 ibid art. 5 .
} 
recommendations to the Member State in question, as part of the MIP's 'preventive action'. ${ }^{37}$ In this regard, the regulation specifically refers to article 121(2) TFEU.

Where an excessive imbalance is detected, the Council may open an Excessive Imbalance Procedure ('EIP') and recommend the Member State to take corrective action. The recommendation will 'specify a set of policy recommendations to be followed' and a deadline for doing so. ${ }^{38}$ This procedure is based on article 121(4) TFEU, as specified in article 7(2) of the MIP-regulation. Following the opening of an EIP, the Member State must submit a corrective action plan ('CAP'), setting out specific policy actions it has implemented or intends to implement. These actions are to be 'based on' the recommended action stipulated by the Council (article 8(1)). The policy response of the Member State should cover the 'main economic policy areas, potentially including fiscal and wage policies' ${ }^{39}$ The Council may adopt a decision of non-compliance with such a recommendation by reverse Quality Majority Voting ('QMV'). The condition to establish non-compliance is that the Council, on the basis of a Commission report, considers that the Member State 'has not taken the recommended corrective action' (article 10(4)). If the Member State continues its failure to implement the recommended corrective action, the Council may, following a recommendation by the Commission, impose fines and interest-bearing deposits on Eurozone States. ${ }^{40}$ Financial sanctions can only be imposed on Eurozone states. ${ }^{41}$ The decisions are taken by the Council by reverse QMV. ${ }^{42}$ An EIP is cancelled when the institutions consider that the excessive imbalance has ceased to exist (article 11). The financial sanctions will be further discussed below.

In 2019, the Commission concluded on the basis of its in-depth reviews that ten Member States were experiencing imbalances, three Member States were experiencing excessive imbalances, and one Member State were not experiencing any imbalance at all. In 2018, the respective numbers were eight and three. ${ }^{43}$ However, no Member State have been subjected to the EIP yet (2019).

The recommendations under the preventive action in the MIP and under the EIP are integrated into the Country Specific Recommendations ('CSRs') that are adopted as a part of the European Semester of economic policy coordination ('European Semester'). Recommendations in the framework of the preventive arm of the Stability and Growth $\mathrm{Pact}^{44}$, the Europe 2020 strategy, the BEPGs, the Employment Guidelines, and the MIP (which encompass both the recommendations under the preventive action and under the EIP), are integrated into the single package, that is the CSRs. Macroeconomic issues are also connected to the SGP in that the Commission, when it is assessing the level of deficit in a

\footnotetext{
37 ibid art. 6.

38 ibid art. 7(2).

39 ibid paras, 15-19.

40 Regulation (EU) No 1174/2011 (n 32), art. 3.

41 ibid art. 1(2).

42 ibid art. 3(3).

${ }^{43}$ European Commission, '2019 European Semester: Assessment of progress on structural reforms, prevention and correction of macroeconomic imbalances, and results of in-depth reviews under Regulation (EU) No 1176/2011', COM (2019) 150 final, 5-7.

44 The SGP encompass Council Regulation (EC) 1466/97 on the strengthening of the surveillance of budgetary positions and the surveillance and coordination of economic policies [1997] OJ L209/1 and Council Regulation (EC) 1467/97 on speeding up and clarifying the implementation of the excessive deficit procedure [1997] OJ L209/6.
} 
Member State, shall take into account, inter alia, the economic policies in the context of macroeconomic imbalances. ${ }^{45}$ Based on the report written by the Commission, the Council will decide whether the Member State has taken effective action in response to its recommendations. ${ }^{46} \mathrm{~A}$ fine can be imposed by the Council if it decides that a Member State has not 'taken effective action to correct its excessive deficit'. ${ }^{47}$ Consequently, a failure to properly address a macroeconomic imbalance might lead to the decision that a Member State has taken insufficient action to correct a deficit.

As a part of the Two-pack ${ }^{48}$, regulation 473/2013 ('DBP-regulation') ${ }^{49}$ establishes enhanced monitoring and surveillance of Member State's draft budgetary plans ('DBP's'), in particular the compliance of the plans with the policy guidance provided under the European Semester. The Eurozone Member States must submit their DBPs annually to the Commission and the Eurogroup and they must be consistent with the recommendations issued in the context of the SGP, and any recommendations issued in the context of the European Semester, including the MIP (article 6(1)). The Commission may request a revised plan 'where the implementation of the draft budgetary plan would put at risk the financial stability of the Member State concerned or risk jeopardising the proper functioning of the economic and monetary union'. ${ }^{50}$ The DBP-regulation and the MIP-regulation thus interrelate in two ways. Firstly, the DBP must expressly be consistent with recommendations issued under the MIP-regulation. Secondly, as risks to the proper functioning of the Economic and Monetary Union ('EMU') may determine the existence of macroeconomic imbalances in accordance with the MIP-regulation, it is possible that macroeconomic imbalances can become important in the assessment of the DBPs. By that logic, a revised DBP might be requested if the plan is deemed to insufficiently deal with a macroeconomic imbalance (and thus risk jeopardising the proper functioning of the economic and monetary union). The Commission has only once requested a new DBP, which happened in 2018 in regard to Italy's 2019 DBP. The Commission considered the DBP to be inconsistent with a Council recommendation issued in accordance with the preventive arm of the SGP. This regards the various numerical benchmark rules which are a part of the adjustment path towards the MTO. Furthermore, the Commission noticed that Italy did not comply with the condition of the DBP-regulation to endorse its plan by an independent body. ${ }^{51}$ The Commission noted further that, whilst Italy has the sovereign power to decide their

\footnotetext{
${ }^{45}$ Council Regulation (EC) 1467/97 (n 44), art. 2(3)(b).

46 ibid art. 4(2).

47 Regulation (EU) 1173/2011 of the European Parliament and of the Council on the effective enforcement of budgetary surveillance in the euro area [2011] OJ L306/1, art. 6(1).

48 The Two-pack is a legislative package which consists of Regulation (EU) No 472/2013 of the European Parliament and of the Council of 21 May 2013 on the strengthening of economic and budgetary surveillance of Member States in the euro area experiencing or threatened with serious difficulties with respect to their financial stability [2013] OJ L140/1 and Regulation (EU) No 473/2013 of the European Parliament and of the Council of 21 May 2013 on common provisions for monitoring and assessing draft budgetary plans and ensuring the correction of excessive deficit of the Member States in the euro area [2013] L140/11.

${ }^{49}$ Regulation 473/2013 (n 47).

50 ibid, art. 7(2) and para 20.

${ }^{51}$ European Commission, 'Commission Opinion of 23.10.2018 on the Draft Budgetary Plan of Italy and requesting Italy to submit a revised Draft Budgetary Plan’ C(2018) 7510 final.
} 
'budgetary priorities', it must still comply with the numerical fiscal rules set out in the recommendations under the SGP. ${ }^{52}$

\section{2[b] A constitutional basis}

The legal basis of the MIP-regulation is, as stated above, article 121(6) TFEU which empowers the Union to adopt detailed rules on the multilateral surveillance procedure referred to in articles 121(3) and 121(4) TFEU through the ordinary legislative procedure ('OLP'). Article 121(3) TFEU empowers the Council to:

monitor economic developments in each of the Member States and in the Union as well as the consistency of economic policies with the broad guidelines referred to in paragraph 2, and regularly carry out an overall assessment'.

As such assessments are to be based on 'reports submitted by the Commission', the Commission too is empowered in relation to these monitoring missions and assessments. Article 121(3) TFEU further reads that:

For the purpose of this multilateral surveillance, Member States shall forward information to the Commission about important measures taken by them in the field of their economic policy and such other information as they deem necessary.

It is clear from article 121 TFEU that the multilateral surveillance procedure covers general economic policies, as the 'economic development' is referred to in article 121 (3) TFEU. The range of application of Union action in this competence area therefore regards all aspects of economic policy. On that basis, I argue that the range of application of the power-conferring norms in question (article $121 \mathrm{TFEU}$ ) also includes 'sensitive ${ }^{53}$ policy areas such as taxation, education and the housing market.

However, a broad range of application could be mitigated by a narrower range of regulation. Article 121(2) TFEU empowers the adoption of BEPGs and article 121(4) TFEU empowers the adoption of warnings and recommendations. The recommendations as per article 121(4) TFEU are to be adopted by the Council, and the warnings adopted by the Commission. Regarding the procedure, the article stipulates a QMV for the adoption of the recommendations. The recommendations based on article 121(4) TFEU are connected to a range of application; inconsistency with the BEPG or risk of jeopardizing the proper functioning of the EMU. Again, considering that the procedure in article 121(4) TFEU is connected to the surveillance of article 121(3) TFEU, the Commission and the Council can regard all aspects of economic policy of the Member State when evaluating the consistency with the BEPG or whether the policy risk jeopardizing the proper functioning of the EMU.

As for the wording of article 121(6) TFEU, it confers a competence to detail the 'procedure' of the multilateral surveillance. Consequently, when the Union wants to exercise

52 European Commission, 'European Commission Opinion on the 2019 draft budgetary plan of Italy', (Press Release) MEMO/18/6175.

${ }^{53}$ For example, Garben has stated that ' $[\mathrm{m}]$ ember States are legitimately concerned about granting the EU a hard competence in this area, as they fear it may become a blank cheque for the EU to decide on highly sensitive decisions of a re-distributive nature at the core of their sovereign powers'. Sasha Garben, 'The Constitutional (Im)balance between 'the Market' and 'the Social' in the European Union' (2017) 13 European Constitutional Law Review 23, 43 f (emphasis added). 
its competence to adopt recommendations as per article 121(4) TFEU, a semantic interpretation would imply that article 121(6) TFEU facilitates the adoption of a more detailed procedure than provided in the former, in the form of a regulation adopted in accordance with the OLP. In accordance with such an interpretation, the more detailed provisions must comply with the procedure set out in articles 121(3) and 121 (4) TFEU. This would be necessitated by the range of application of article 121(6) TFEU, compliance with articles 121 (3) and (4) TFEU being a material criterion. Thus, no other actors can be empowered, no other procedure may be facilitated, and the range of application and regulation may not be altered. With that interpretation in mind, article 121(6) TFEU setting out detailed rules cannot empower the Council to adopt any other instrument than a recommendation in the event of inconsistency with the BEPG or when there is a risk of jeopardising the proper functioning of the EMU. Likewise, article 121(6) TFEU cannot empower the Council to act in any other circumstance than in the event of inconsistency with the BEPG or when there is a risk of jeopardising the proper functioning of the EMU.

In line with what has already been discussed, the subject matter of the multilateral surveillance procedure covers all economic policy issues to the extent that it has importance for the coordination of economic policies and convergence of the economic performances of the Member States. In respect of the subject matter of the surveillance and coordination as empowered by the MIP-regulation, which is essentially all economic issues that might be of importance when detecting and assessing an imbalance, the scope of application of article 121 TFEU encompass the subject matter of the regulation.

The Union has the competence to direct recommendations on economic issues to the Member States, firstly on the basis of article 121(2) TFEU and secondly on the basis of article 121(4) TFEU. The latter power-conferring norm regards the situation of an inconsistency with a BEPG or in the event a Member State is jeopardizing the proper functioning of the EMU. The recommendations adopted in response to an imbalance or an excessive imbalance, of which the existence of an imbalance can be established on the basis that it jeopardizes the EMU, are based on article 121(4) TFEU.

The CSRs, of which the recommendations under the MIP are a part, are legally based on article 121(2) TFEU. ${ }^{54}$ Article 6(1) of the MIP-regulation expressly states that the recommendations under the preventive action of the MIP are legally based on article 121(2) TFEU. Conversely, the recommendations under the corrective arm (ie the EIP) are legally based on article 121(4) TFEU as per article 7(2). The ranges of regulation as per these Treaty provisions encompass recommendations. The Union has therefore complied with the range of regulation is this regard.

In conclusion, when the Council is adopting recommendations in response to an imbalance or an excessive imbalance, it is acting within the competences conferred upon it in relation to the ranges of application and regulation.

One can of course question whether the Treaty provisions basing the BEPGs restricts the detail of these guidelines. This was of less interest prior to the adoption of the MIPregulation, since there was limited means of enforcement. With the introduction of financial sanctions and an obligation to comply with (take) recommended policy action under the EIP, the more detailed the recommended action, the more power the Member States are subjected

\footnotetext{
${ }^{54}$ Note that they are also legally based on article 148 TFEU as regards employment guidelines.
} 
to. This is because the hierarchical relationship between the power conferring norms concerns the level of compliance necessitated. It is logical that the more detailed the recommendation, the more aspects require compliance. Of course, this does not say anything about the content of the recommendation, ie if it regards 'sensitive' aspects of economic policy. Semantically then, the power-conferring norm (article 121(2) TFEU) does not limit the detail of the recommendations ('broad' is a vague word). The limit would rather be argued from a teleological perspective, in line with the underlying principles of State sovereignty in policy areas requiring democratic legitimacy. In that regard, the German Constitutional Court has already flagged its intention to uphold parliamentary sovereignty over tax issues. ${ }^{55}$ In my view, the (possible) unconstitutionality does not lie in the (more or less detailed) recommendations in relation to the economic development of the Member States, but in the possibility to enforce them which will be discussed below.

In accordance with the MIP-regulation, the Council may adopt decisions establishing non-compliance with a Council recommendation adopted under the EIP. Considering that the power-conferring norms in question, which are relied on as legal bases, do not stipulate Council decisions within its ranges of regulation, the Union has acted outside of its competence when adopting decisions of non-compliance. As it changes the legal position of the Member states (by holding in legally non-compliance), without their consent or dissent, the Council is exercising legal power by its adoption. ${ }^{56}$ The decisions are also significant in that they are connected to the adoption of financial sanctions, which will be discussed below.

It has been proposed that the MIP-regulation unjustifiably, from a perspective of competence, go beyond the scope of article 121 TFEU. Hinarejos describes the introduction of the MIP-regulation as extending the surveillance and enforcement of numerical fiscal rules to the surveillance of national fiscal and economic policy choices. She argues that this 'contributes to a progressive blurring of the distinction between fiscal rules and more delicate, policy-based decisions' ${ }^{57}$ She further argues that the Union's competence associated with numerical fiscal rules in comparison with economic policy is much stronger, which is reasoned by the fact that numerical fiscal rules are seen as apolitical and are connected instead to the currency union (wherein the Union has exclusive competence). ${ }^{58}$ In my view, the argument presented by Hinarejos is rather vague and the fact that the Union previously did not pursue general fiscal and economic policy does not mean that it could not legally do so. In line with what I have argued above, the Union has not acted outside its competences when adopting recommendations under the MIP. Macroeconomic policy is a more delicate policy area, and the Union admittedly has a larger discretionary power since the MIP is controlled less by numerical fiscal rules than the EDP is. However, a more credible argument has been put forth by Bieber, who described the institutional implementation of the multilateral surveillance procedure as the product of a 'dormant substantive competence' and he holds that the Union has interpreted the 'procedural power' of multilateral surveillance broadly. ${ }^{59}$

\footnotetext{
55 See comments by Hinarejos (n 8) 148-149, on: BVerfG, 2 BvR 987/10 et al., Decision of 7 September 2011; BVerfG, 2 BvR 1390/12 et al., Decision of 12 September 2012.

${ }^{56}$ In accordance with MacCormick's theory of legal power, see MacCormick (n 19) $493 \mathrm{ff}$.

${ }^{57}$ Hinarejos (n 8) 71.

58 ibid 72-73.

${ }^{59}$ Bieber (n 28) 92.
} 


\section{2[c] Influencing or dictating the Member States' policy choices?}

In accordance with the order depicted above, the Union not only monitors the policy choices of the Member States, but also tries to influence the policy choices of the Member States (by the CSRs including the recommendations under the MIP) and in cases of economic distress in the Member States, may enforce its visions of the appropriate policy response in the Member State as per the EIP. To say that the Member States are free to form their economic and fiscal policy completely autonomously as long as they adhere to the numerical fiscal objectives is therefore not correct. Roland Bieber considers that recommendations do not to alter the allocation of powers between the Union and the Member States ${ }^{60}$ As I will argue herein, I am of the opposite conviction.

The relationship between the power-conferring norms of the Member State and that of the Union can be viewed on a vertical and horizontal level in accordance with Tusseau's theory. As to the vertical relationship, which regards the range of application, the Member States are by virtue of their sovereignty not limited in regard to the range of application of their economic policies. The power-conferring norms in the TFEU empowers the adoption of recommendations which, by its nature, respond to the same range of application (ie the economic policy within the Member State). Consequently, the power-conferring norms overlap on a horizontal level.

Moving further to the issue of the hierarchical relationship, article 121(4) TFEU states that the Member States' respective economic policies must be 'consistent with' the BEPGs. In accordance with Tusseau's theory, this would entail that the policies do not have to conform with the BEPGs, conformity being the strictest version of primacy, but must be compatible with them, which only requires 'a simple absence of conflict'. Of course, as these are 'guidelines' of 'broad' character, an absence of conflict is more easily achieved than it would be if the power-conferring norm was detailed, thus diluting the hierarchical relationship between the national and EU norms. On the other hand, the CSRs have been described as getting progressively more detailed. ${ }^{61}$

The language that is used in the MIP-regulation is ambiguous as to the degree of compliance between the CAP and the Council recommendations that is necessitated. It is stated that the recommended action is to be 'followed' (article 7(2)) which contrasts the language of article 8(1) that stipulates that the policy response should be 'based on' the recommendation. Following is semantically stronger; you follow an order for example. Conversely, basing an action on the recommendation only implies that the recommendation should be a starting point. Also inviting a stricter conformity is the wording of article 10(2), stipulating that non-compliance shall be established if the Member State 'has not taken the recommended corrective action'. In conclusion, the wording of the articles renders the degree of compliance needed unclear.

As for a teleological interpretation, the objective of the EIP is essentially to ensure the functionality of the EMU. In addition, an EIP must be cancelled if an imbalance no longer exists. Considering that a decision establishing non-compliance is contingent on an ongoing EIP, such a decision cannot be rendered if the EIP is cancelled. And as an EIP must be

\footnotetext{
60 ibid.

${ }^{61}$ Hinarejos (n 8) 163. This development is seen by Hinarejos as one of the possible ways forward for the integration process, at the same time challenging its appropriateness, see ibid $188 \mathrm{ff}$.
} 
cancelled following the ending of an imbalance, the fact that a Member State 'has not taken the recommended corrective action' would not justify a non-compliance decision in the event of the extinction of an imbalance. In such a situation, the action of the Member State does not even have to be compatible with the recommendation of the Council as to the measures taken, only to the effect (that is to end the imbalance and ultimately ensure the functionality of the EMU). What one can deduce is that the Member States' policy responses when they are subject to an EIP must to some degree comply with the Council's recommendation if the imbalance persists (meaning that the effect is not satisfied), and that they cannot be reprimanded if they follow those recommendations. If they do not follow the recommended action, then they must attain the effect intended with the recommended action (namely to end the imbalance) in order to avoid the risk of a decision of non-compliance.

Article 121(4) TFEU only empowers non-legally binding instruments. If one employs a concept of legal power and the relationship between power-conferring norms as I have done, the issue of whether the norm is legally binding or not is not decisive in determining the vertical or hierarchical relationship between the power-conferring norms. What this issue does affect is the accountability of the Member State. Undeniably, the absence of enforcement mechanisms has proven to be a hindrance to the compliance with the CSRs as demonstrated above. In that regard, the legal power of the Union can be seen as meaningless; the Union screaming its CSRs into a void. However, as will be noticeable from the subsequent subchapter, the interplay between hard law and soft law in the macroeconomic framework adopted after the crisis will affect this assessment. This conclusion is also modified by the introduction of the reverse QMV which will be discussed in relation to legal power in subchapter 4 of this chapter.

Lastly, I would like to clarify that stating that the recommendations are hierarchically superior to national budgets is not to be interpreted as implying anything in regard to the principle of primacy of EU law. In other words, even as I argue that there exists superiority of the CSRs in light of Tusseau's theory, I am not arguing that a national body is ought to disapply national budgetary provisions in favour of the CSRs, which the EU principle of primacy would require.

\subsection{DIFFERENTIATED INTEGRATION: THE USE OF ENHANCED COOPERATION}

Tuori and Tuori argues that there is an 'ongoing constitutional mutation in [the economic] field $[. .$.$] aimed at removing obstacles to a further differentiation of the Eurozone from the$ rest of the Union" ${ }^{62}$ and Bieber has described this development as a 'shift in the substantive economic competences' from the Member States to the Union ${ }^{63}$. The culprit identified for this development is the use of enhanced cooperation. These scholars argue that enhanced cooperation has dramatically impacted the institutional practices of the Union in the area of economic policy.

\footnotetext{
${ }^{62}$ Tuori and Tuori (n 9) 171.

${ }^{63}$ Bieber (n 28) 93.
} 


\section{3 [a] Using enhanced cooperation to further Union competences?}

Above, I accounted for theories on EU constitutionalisation in which the practices of the institutions may provide insight into the nature of the competence in a certain area. With the relatively extensive use of enhanced cooperation in the area of economic policy, EU constitutionalisation in general could be regarded to enter unchartered territory. This is because, as I will argue, the Union has used enhanced cooperation in a way to further its competences.

Enhanced cooperation may be used in the non-exclusive areas of Union competences, and such cooperation 'may make use of its institutions and exercise those competences by applying the relevant provisions of the Treaties' ${ }^{64}$ Enhanced cooperation should be a 'last resort' when it has been 'established that the objectives of such cooperation cannot be attained within a reasonable period by the Union as a whole'. ${ }^{65}$ Measures adopted by enhanced cooperation must comply with the Treaties and in general with Union law and may not 'undermine ... the economic, social and territorial cohesion ... between the Member States'. ${ }^{66}$ It must also 'respect the competences, rights and obligations of those Member States which do not participate in $\mathrm{it}^{967}$ and all Member States must be able to join at all times ${ }^{68}$.

To note is that the reach of article 136(1) TFEU (which empowers enhanced cooperation in the Euro Area) has not yet been subjected to judicial review. In fact, since enhanced cooperation before the Lisbon treaty usually took place outside the scope of the Treaties, the Court's jurisdiction was curtailed with the effect that the nature in general of this mechanism is rather unexamined. ${ }^{69}$ In that regard, it has been pointed out that the 'constitutional scope' of enhanced cooperation remains unclear. ${ }^{70}$

Tuori and Tuori argues that the wording of article 136 (1) TFEU implies that not only the procedure but also the substance of articles 121 and 126 TFEU must be respected. By that logic, they question the constitutionality of the power to impose financial sanctions, the monitoring of annual budgets, and the recourse to reverse QMV. Furthermore, they reason that the principle of conferral motivates a limit to the extension possible by enhanced cooperation, stating that: 'If, however, creating new competence for EU institutions for strengthening coordination and surveillance of euro states' budgetary discipline were allowed, it is difficult to see how the limits of such competences should be defined'. ${ }^{71}$

Conversely, Piris argues that the scope of article 136 TFEU is 'extremely wide', focusing instead on the broad language used in the article ('strengthening the coordination

\footnotetext{
64 Article 20(3) TEU.

65 Article 20(2) TEU.

66 Article 326 TFEU.

${ }^{67}$ Article 327 TFEU.

68 Article 328(1) TFEU.

${ }^{69}$ Ester Hernil-Karnell, 'Enhanced cooperation and conflicting values: are new forms of governance the same as 'good governance'?' in Martin Trybus and Luca Rubini (eds), The Treaty of Lisbon and the Future of European Law and Policy (Edward Elgar 2012), 149.

${ }^{70}$ Federico Fabbrini, 'Enhanced Cooperation under Scrutiny: Revisiting the Law and Practice of Multi-Speed Integration in Light of the First Involvement of the EU Judiciary', (2013) Legal Issues of Economic Integration 40(3), 197, $198 \mathrm{ff}$.

71 Tuori and Tuori (n 9) $170 \mathrm{ff}$.
} 
and surveillance' and 'setting out policy guidelines'), which are conditions he argues a broad array of measures could meet. ${ }^{72}$

With such a divided academic background, I will embark on forming my own conclusion on the basis of Tusseau's theory on power-conferring norms. In line with the argumentation below, my conclusion will parallel Tuori's and Tuori's assessment rather than Piris'.

The Enforcement-regulation provides for the use of fines and deposits adopted by a Council decision on the basis of a recommendation by the Commission by reverse QMV. The legal bases of the Enforcement-regulation are articles 121(6) TFEU and 136 TFEU. However, as I explained above, the range of application of article 121(6) TFEU s connected to articles 121(3) and 121 (4) TFEU. Article 121(4) TFEU only provides for the use of a recommendation as a sanction for inconsistency with the BEPG or in the event of a 'risk of jeopardising the proper functioning' of the EMU, and such a recommendation is to be adopted on the basis of a normal QMV.

Firstly, the regulation provides for the adoption of a decision as opposed to a recommendation. These are two different instruments, and especially, a decision is legally binding whilst a recommendation is not (article 288 TFEU). Thus, the Union has not acted within its range of regulation when providing for a decision instead of a recommendation. Secondly, article 121(4) TFUE limits the procedure to normal QMV, but the regulation stipulates reverse QMV. Therefore, the Union has not complied with the power-conferring norms also in regard to the procedure.

The question is then if article 136 TFEU could provide for the adoption of a decision based on reverse QMV. The provision provides for the adoption of 'measures' which is a broad term that could include decisions. However, the article also states that the Council shall act 'in accordance with the relevant procedure from among those referred to in Articles 121 and 126, with the exception of the procedure set out in Article 126(14)'. As for the wording in the article, I hold that the measures to enhance cooperation are to be in accordance with the relevant procedure in articles 121 and 126 TFEU. As such, enhanced cooperation relating to article 121(6) TFEU must then comply with the procedure set out therein. With procedure, it is contextually logical to be referring to the procedure of adoption of a measure. For article 121(6) TFEU then, that would entail a procedure of normal QMV when adopting recommendations on the basis of article 121(4) TFEU and the OLP when adopting procedural rules on the multilateral surveillance in the form of regulations. On the other hand, it could be argued that the range of regulation is not identical to procedure, and thus, the wording of article 136 TFEU does not limit the range of regulation in the same way as it limits the procedure. That would mean that article 136 would, for example, open for the competence to adopt a decision instead of a recommendation. Furthermore, such an interpretation would enable other actors to be empowered, for example, expanding the power of the Commission beyond the use of a warning. If one employs such an interpretation, the empowerment of the Council by the Enforcement-regulation to adopt fines and deposits is not contrary to its conferred powers since article 136 TFEU only limits the procedure (being a QMV). Perhaps the fact that article 136 TFEU provides for a 'strengthen' coordination and surveillance is the reason why the article has undoubtedly been

${ }^{72}$ Jean-Claude Piris, The Future of Europe - Towards a Two-Speed EU? (Cambridge University Press 2011), 107. 
interpreted so broadly by the Union legislator. The language is ambiguous; introducing the legal power to adopt financial sanctions by Council decisions does strengthen framework. This was also the express purpose of the financial sanctions; the Union was unhappy with the level of compliance.

A teleological interpretation would have to incorporate the purpose behind enhanced cooperation, namely that 'objectives of such cooperation cannot be attained within a reasonable period by the Union as a whole'. Seemingly, it regards political unwillingness of certain Member States to further integration rather than bypassing legal conditions. ${ }^{73}$ Such an interpretation of the objective underscores that the legal power of the Union is not governed by provisions of enhanced cooperation, as those provisions only facilitate powerin-fact. In light of this, the use of the word 'procedure' in article 136 TFEU even in combination with the aim at strengthening surveillance and coordination would not refer to procedure in a strict sense. Procedure, instead, would mean all the conditions laid down in articles 121 and 126 TFEU.

Thus, I conclude that it would not be allowed to change the empowered actor(s), the procedure, the range of regulation or the range of application.

Furthermore, the intended consequence of the enhanced cooperation is clearly to enhance the efficiency of the framework. ${ }^{74}$ This is compatible with the 'strengthening' of the multilateral surveillance procedure semantically provided by article 136 TFEU. However, every centralized measure could be regarded to strengthen surveillance, which would give a free-pass for the Union to adopt ever more intrusive measures. In light of the principle of conferral, integrated into the Treaties, of which the aim is to delimit the Union's competences, such an interpretation is counter to the purpose of the principle.

Consequently, as the Enforcement-regulation, which is based on article 121(6) TFEU in combination with article 136 TFEU, provides for the adopting of financial sanctions by a Council decision by reverse QMV, it is doubtful that it is compatible with the competence of the Union as conferred by these provisions. The problem is then, not that it provides for the adoption of financial sanctions, which is not countering to ensuring consistency with the BEPG or to avoid risks of jeopardising the functionality of the EMU, which would be the material criterion. Instead, the problem lies with the range of regulation and the procedure stipulated by the relevant power-conferring norms.

\section{3.[b] Reconciling cohesion in a differentiated economic landscape}

It has been visible in the explication of the economic and fiscal framework in the Union that much of the legislation adopted would not have been possible without the possibility of enhanced cooperation. Emerging is a landscape of economic policy wherein the rules for the Euro States and the rest of the Member States are increasingly different. As a reminder, 19 of the 28 Member States (including the UK at the moment) are part of the Eurozone. 6 Member States are not currently part of the Eurozone but are obligated to join once they

\footnotetext{
${ }^{73}$ See also Fabbrini (n 70) 203.

${ }^{74}$ See for example Regulation (EU) No 1174/2011 (n 32), para 20.
} 
meet the criteria. The UK and Denmark have a derogation under the Treaty, and Sweden has a de facto opt-out. ${ }^{75}$

EU constitutionalism have traditionally been centred around the idea of an 'ever closer Union $^{976}$ depending on unity. The nature of enhanced cooperation opposes this as it is based on differentiation. The assumption previously was that the legal threshold for applicability of enhanced cooperation was high, which was perceived as a sign of aversion to differentiation. ${ }^{77} \mathrm{~A}$ possible explanation for the successful use of enhanced cooperation in recent years, successful as it has de facto been used whereas enhanced cooperation had never been put into practise prior to $2010,{ }^{78}$ is that the EU now has competence in 'sensitive policy areas ${ }^{79}$ which economic policy is usually considered to be. In other words, the need for enhanced cooperation might be less prominent in areas in which the Member States are more likely to agree on, thus not resulting in a 'last resort' situation.

I already proposed that enhanced cooperation opposes Member State unity, but what do I base this assumption on?

On the one hand, Deirdre M. Curtin and Ige F. Dekker argue that the possibility provided by enhanced cooperation for the EMU to create a 'legal sub-system' does not in itself threaten the unity of the Union as long as the legal practices are governed by common EU principles, objectives and concepts. Of particular importance in this regard they hold the principle of coherence ${ }^{80}$ which they describe as the objective that:

The different parts of a legal order are connected by common basic legal concepts uniting competing and sometimes even contradictory of such basic legal concepts used in the different legal sub-systems of the legal institution. ${ }^{81}$

In this case then, the EMU and the periphery must be connected by common basic legal concepts which unite the competing or contradictory basic legal concepts of the two systems. In this regard, all of the Member States have to regard their economic policies as a matter of common concern and coordinate them within the EU framework. The objectives as stated in articles 119 and 120 TFEU are also common to all Member States. In fact, also the proper functioning of the EMU is a common objective as it is a protected interest in article 121(4) TFEU. ${ }^{82}$

On the other hand, in the field of divorce wherein enhanced cooperation was first used, Jan-Jaap Kuipers expressed concern that enhanced cooperation used to tame a controversial issue in substance may 'not lead to a two-speed Europe, but rather push Europe

\footnotetext{
${ }^{75}$ Francis Snyder, 'EMU - Integration and Differentiation: Metaphor for European Union' in Paul Craig and Gráinne de Búrca (eds), The evolution of EU law' (2nd edn, Oxford University Press 2011), 703.

${ }^{76}$ See the preamble of both the TEU and the TFEU which feature this term.

${ }_{77}$ Matej Avbelj, 'Differentiated Integration - Farewell to the EU-27' (2013) German Law Journal 14(1) 191, 201.

78 ibid 200.

79 ibid $201 \mathrm{ff}$.

${ }^{80}$ Deirdre M. Curtin and Ige F. Dekker, 'The European Union from Maastricht to Lisbon: Institutional and Legal Unity out of the Shadows' in Paul Craig and Gráinne de Búrca (eds), The evolution of EU law (2nd edn, Oxford University Press 2011), 173.

81 ibid 158.

${ }^{82}$ See a discussion on the proper functioning of the EMU as a protected interest in chapter 3.6 below.
} 
into two directions'. ${ }^{83}$ In that regard, Fabbrini has argued that enhanced cooperation may only be used if the Member States wish to proceed with integration in a new policy area. He expresses concern that the opposite use would:

$[\ldots]$ in fact ... not serve the goal of furthering the process of EU integration but would rather allow a group of states to unilaterally impose its position in circumvention of the EU decision-making procedure, with potentially damaging effects on the integrity of EU law. ${ }^{84}$

Federico Fabbrini argues that the requirement that enhanced cooperation does not affect the non-participating States, entails that the production of it may not bind those states or become a part of the Union acquis ${ }^{85}$ The aim with the enhanced cooperation in relation to the macroeconomic framework is to make that framework effective. In that regard, the measures themselves are not adverse in relation to non-participating Member States. On the other hand, concerns have been voiced as to the emergence of a euro area 'core', in which the Eurozone countries, deeper integrated, would display 'dominant political influence within the European Council and acting as a powerful legal block also within the Councill. ${ }^{86}$ This is especially delicate in regard to the EIP in which only a majority against an opening of an EIP or the establishing of non-compliance is needed.

It might still be too early to determine the long-term effects of the differentiation of the Eurozone States. The framework is quite young, and the most intrusive measures, namely financial sanctions, are at this point unused. In what ways the differentiation might affect the allocation of power not only between the Union and the Member States in general, but internally between the Eurozone and the non-Eurozone states, are probably going to be further discussed in the future. For now, I claim it suffices to determine that there are concerns about the differentiation in the field of economic policy.

\subsection{INTRODUCING ACCOUNTABILITY: ENFORCEMENT MECHANISMS}

The economic and fiscal framework prior to the adoption of the six-pack in response to the crisis was considered too ineffective. Therefore, the six-pack introduced and made more effective financial sanctions in this area. ${ }^{87}$ The possibility for EU to enforce its powers on the Member States is another layer of the relationship between the two legal orders.

\section{4[a] The nature of recommendations}

The Treaty recognizes that the Union is exercising competence when its adopting directives, regulations, decisions, recommendations and opinions (article 288 TFEU). The same article stipulates that directives, regulations and decisions are legally binding. The legal effect of recommendations and opinions are however not provided for. Generally, recommendations

\footnotetext{
${ }^{83}$ Jan-Jaap Kuipers, 'The Law Applicable to Divorce as a Test Ground for Enhanced Cooperation ' (2012) European Law Journal 18(2) 201, 213.

${ }^{84}$ Fabbrini (n 67) 208.

85 ibid 203.

86 'What do we want? Flexibility! Sort of ... When do we want it? Now! Maybe...' (Editorial Comments). (2013) Common Market Law Review 50(3) 673, 680.

${ }^{87}$ European Commission, EU Economic governance "Six-Pack" enters into force, MEMO/11/898 (n 7).
} 
are attributed the group soft law instruments, which are distinguished from hard law instruments. ${ }^{88}$ As for the distinction between hard law and soft law, Fabien Terpan argues that the categorization of an instrument depends both on the existence of an obligation and its enforcement. Enforcement is key to understanding how the norm intends to ensure that the obligation is fulfilled or that the assigned goal is achieved. ${ }^{89}$ Terpan maintains that '[p]rogrammes, general guidelines and objectives cannot be any more than weak forms of obligations'. The reasons he provides are that the Member States do not commit to achieving specific objectives, that they are not transposable to national law or directly applicable, and that they must only be 'taken into account' by the national authorities. ${ }^{90}$ The responses to the euro area crisis in the form of adopted measures lies at the heart of the debate on hard law and soft law in the EU legal order.

The CSRs cover substantive economic policy, and even as their precision vary thus far, the constitutional limit of this precision is not clear. This is especially the case considering that the CSRs combine recommendations based on several different instruments. Even as the BEPGs are supposed to be 'broad' in accordance with article 121(2) TFEU, recommendations may also be directed on the basis of article 121(4) TFEU for which no such limit is posed.

It is possible to delve deeper into the impacts of recommendations as a union instrument, however, I will stop short of such a dive in consideration of the recommendations' interaction with decisions in the context of macroeconomic governance, discussed below.

\section{4[b] Freedom conditioned on economic health}

Financial sanctions in the EIP are connected to an event of non-compliance with a Council recommendation. As the Member States cannot produce Council recommendations, they have not 'given up' a power they previously possessed. The competences of the Union versus the Member States are thus not overlapping. This is in contrast to the CSRs, where the Member States have 'given up' their power to autonomously decide their economic policies. The financial sanctions, I would argue, do not in themselves change the allocation of power between the Member States and the Union from a legal perspective. A financial sanction does not implicate the hierarchical relationship between Union law and national law; if Union law in a certain field is considered superior to national law, the absence of financial sanctions does not change that. The reason the question of hierarchy is not relevant is because, as I stated, there is no overlap of competences; there is no division of the ranges of application between the power of the member States and the Union since the Member States do not possess this power at all.

Kenneth Armstrong's hybrid form of 'new governance'; hybridity between rules based and coordination-based governance; is attaining to explicate how instruments and modes of governance are utilized in a new way to optimize governance capacity. In the new governance

\footnotetext{
${ }^{88} \mathrm{I}$ have relied on the distinction and explanation of soft law and hard law made by Terpan in Fabien Terpan, 'Soft Law in the European Union-The Changing Nature of EU Law' (2015) European Law Journal 21(1) $68,70 \mathrm{ff}$.

89 ibid $72-73$.

90 ibid 81.
} 
system, the initial recommendations, which are a token of the soft Open method of coordination ('OMC') and a coordination-based governance, can result in decisions of noncompliance and even sanctions in the form of fines, which in contrast are characteristics of rules-based governance. ${ }^{91}$ Thus, Armstrong describes an interplay between rules-based and coordination-based governance in fiscal governance related to the SGP which 'erodes the dichotomous relationship between the 'hard' sanctions of the EDP and the 'soft' persuasion of economic policy coordination'. ${ }^{92} \mathrm{I}$ argue the same can be said for the EIP. In constitutional terms, the recommendations under the EIP are not legally binding per se as their source is a non-legally binding instrument. However, as non-compliance with a recommendation ('not taken the recommended action') may result in financial sanctions, the recommendations are connected to an enforcement mechanism. Even though, as I argued, the financial sanctions themselves do not influence the hierarchical relationship between the norms of the two legal orders, the consent or dissent needed of the Member States to the sanctions is affected. The Member States' possibility to consent/dissent, not only to the introduction of an obligation to take the recommendations into consideration, but to actually implement the recommendation is decreased. If the (Euro Area) Member State dissents to take the recommended action under an EIP, a decision establishing non-compliance may be accompanied by financial sanctions. This is a system designed to make effective the framework, to decrease the level of dissent.

Following this line of thought, the recommendations should be regarded as legally binding under an EIP regardless of their formal form (recommendations are not legally binding), because not complying with them may result in financial sanctions. The insertion of a Council decision (ie formally legally binding) establishing non-compliance is perhaps reasoned by the fact that it would be hard to swallow financial sanctions on the basis of a formally non-legally binding instrument. The decisions therefore work as a conversion instrument in regard to enforcement. However, the Union lacks competence in accordance with the chosen legal basis to adopt decisions, in accordance with the line of argument presented in the previous chapter. Even as it may be argued that financial sanctions are based on enhanced cooperation, the EIP may be launched also in relation to a non-euro area Member State, a situation wherein article 136 TFEU is not applicable. The decision itself establishing non-compliance is therefore not complying with the power-conferring norm of which its empowerment rests on.

Concerning the issue of accountability, Armstrong highlights the inadequacy of attributing the traditional accountability method to this new form of governance, as the actors in the new form are the Commission (initiating) and the Council (recommending/deciding) whereas the old method heavily involved the Court in the form of infringement actions. Secondly, he highlights how financial sanctions are, albeit connected to benchmarks (eg the medium-term objectives in relation to the SGP, the indicators in the scoreboard in relation to the MIP-regulation) but the decisions of non-compliance rest on discretionary evaluations in which the Commission may base its action on evaluations differing from that of the Member States. These evaluations rely on the gathering of data as

\footnotetext{
${ }^{91}$ Kenneth Armstrong, 'The New Governance of EU Fiscal Discipline' (2013) European Law Review 38(5) 601, $609 \mathrm{ff}$.

92 ibid 612.
} 
a part of the multilateral surveillance procedure which is now embedded in the European Semester, in other words, as a part of the coordination efforts. Thus, the rules-based governance associated with the sanctions regime is operating within a coordination-based governance 'in a hybrid structure. ${ }^{93}$ As regards this discretionary power, not only does the Commission decide which factors are a part of the scoreboard but also, the broad definitions of an imbalance and an excessive imbalance make the establishing thereof sensitive to discretionary evaluation. This discretionary power in relation to establishing an imbalance or excessive imbalance also affect the allocation of powers in a centralize-friendly way, considering that it opens the possibility of enforcing the norms produced by the Union.

In summary, financial sanctions which are provided for in the Enforcement-regulation do not do not relate horizontally to a Member State's power-conferring norm. However, they operate as a form of enforcement mechanism for the legal power exercised by the Union in the macroeconomic framework in relation to the otherwise non-legally binding recommendations.

Bieber argues that 'the autonomy of the Member States in [the economic policy] area exists only to the extent that the criteria established by the Union are met'. ${ }^{94}$ The opening of an EIP could be attributed that description. Under the EIP, the Union may consider most areas of economic policies of a Member States and recommend policy response to which the Member State must comply with in order to guarantee absence of financial sanctions. Thus, when a Member State is experiencing macroeconomic imbalances, the Member State's leeway for action will be limited considering that the Union may then produce norms which affect the Member States' power to act autonomously in the policy area.

\section{$3.4[c]$ Briefly on the compliance research}

As already mentioned, the pre-crisis framework was considered ineffective which was partly reasoned by the low-level of compliance with the SGP. The reformation in 2011 introduced financial sanctions, which might be a sign that the OMC did not deliver a level of compliance needed especially during the crisis. Which was explained above, the macroeconomic framework contains enforcement mechanisms different from those generally associated with the OMC. The purpose of the article is not to examine the national implementation of the Union's recommendations, which would also consider the allocation of power that has taken place in practice. The national implementation would enrich the discussion on how much the Union's exercise of its competence affects the competences of the Member States. However, such an endeavour would be too comprehensive for the present article and I find it sufficient to provide a brief insight into the research on this issue.

The internal institutional research on the national compliance with the CSRs have demonstrated that most CSRs receive 'limited' or 'some' progress. However, the researchers clarify that it is difficult to quantify qualitative assessments in this regard. The level of detail and quantity of recommendations differ in relation to the severity of the economic situation in the Member State. Moreover, many of the recommendations relate to long-term challenges and thus requires substantial institutional and structural reform, which might be difficult to account for when looking at a time span of implementation of less than a year (which was

\footnotetext{
93 ibid 612-613.

${ }^{94}$ Bieber (n 28) 92.
} 
the case in this study). The researchers also draw attention to the fact that the Commission in dubio attributed the progress to a lower category. In relation to policy areas, implementation was highest for the sector of financial and public finances reforms. Lowest implementation was been noted for tax reforms. ${ }^{95}$ External research also points to a low degree of compliance with the CSRs, being a bit more pessimistic than the internal research. In particular, a problem identified with the 2015 CSRs was an inconsistency between the Euro Area recommendations and the CSRs. ${ }^{96}$

However, the strengthening of fiscal and economic surveillance is still relatively young which might impact the conclusions that can be drawn of the effectiveness of the legislation. Additionally, the EIP has not yet been launched, which might also affect the assessment of effectiveness.

\subsection{THE FACE BEHIND CHANGE: ACTORS OF INTEGRATION}

The question of the allocation of power between the Member States and the Union inevitably involves the topic of which kind of entity the $\mathrm{EU}$ is. The EU model is constructed as to accommodate the interests of three distinct groups, namely: the citizens through the European Parliament; the sovereign states through the Council; the supra-national through the Commission. This model is built rather on the idea of separation of interest than separation of power. ${ }^{97}$ In this regard, it has been noted that an intergovernmental decisionmaking structure would typically entail consensus by the Member State; in constitutional terms, require unanimous voting in the Council. Conversely, a supranational structure is at hand when the Union is acting independently in a federal-like relationship vis-à-vis the national governments. Such an arrangement would be facilitated by majority voting in the Council. ${ }^{98}$ Therefore, inter-institutional distribution of power has an impact, not only internally but also on the distribution of power between the Member States and the Union. On that background, it is important to keep the makeup of the actors involved in mind when assessing the allocation of power between the Member States and the Union. More specifically, where unanimity in the Council is required, power cannot be exercised to the dissent of a Member State as it is able to block that exercise by their vote. Conversely, where binding measures are adopted by the Commission or where a judgement is made by the Court, the exercise of power is supranational in nature since the Member States do not have representatives therein that act on their behalf.

\section{5 [a] The empowerment of the Commission}

The MIP-regulation is legally based on article 121(6) TFEU. The multilateral surveillance procedure entails that recommendations in response to an inconsistency with a BEPG or in

\footnotetext{
${ }^{95}$ Servaas Deroose and Jörn Griesse, 'Implementing economic reforms - are EU Member States responding to European Semester recommendations?’, (ECFIN Economic Brief Issue 37/October 2014).

${ }^{96}$ Zsolt Darvas and Álvaro Leandro, 'The limitations of policy coordination in the euro area under the European Semester' (Bruegel Policy Contribution Issue 2015/19 2015), 6 ff.

${ }^{97}$ See Giandomenico Majone, 'The Community Method' in Dilemmas of European Integration, (Oxford University Press 2005).

${ }^{98}$ Stephen C. Sieberson, 'Inching toward EU Supranationalism - Qualified Majority Voting and Unanimity under the Treaty of Lisbon' (2010) Virginia Journal International Law 50(4) 919, 923.
} 
the risk of jeopardizing the functionality of the EMU are to be taken by a QMV in the Council. Article 121(4) TFEU does in that regard not deviate from the general rule stipulated in article 16(3) TEU. In consideration of Tusseau's theory, article 121(6) TFEU in combination with the other subparagraphs of article 121 TFEU setting out the multilateral surveillance procedure are the power-conferring norms of which the normative production must comply with.

The MIP-regulation stipulates that a Council decision establishing non-compliance is decided by reverse QMV. In other words, the Union has overstepped its conferred competence by stipulating that a decision can be taken by reverse QMV. It is a very blatant overstep, as in contrast to the financial sanctions, one cannot argue justification by reference to article 136 TFEU. This article is not the legal basis for the MIP-regulation, and the decisions can be taken in regard to all Member States. Taking the Union's recommended action was previously subjected to a soft obligation source (CSRs). The Union legislator has thereby introduced legally binding instruments in the multilateral surveillance procedure.

\section{5[b] Unpoliticized policy steering}

The reverse QMV procedure is a new installation as per the Six-pack. The reverse QMV works - unsurprisingly - in the same manner as a QMV but in reverse. What has been said about a (normal) QMV as regards its supranational nature, is even more true for its reflection, the reverse QMV. A switch from unanimity to QMV removes a veto-power for the Member States, but a switch from (normal) QMV to reverse QMV results in loss for the Member States of their option of political bargaining. The introduction of the reverse QMV has been described as '[freeing] the application of technical rules on fiscal discipline from political interference. ${ }^{99}$ This is due to the fact that, really, only a minority is needed to adopt the Commission's recommendation because only a qualified majority may 'stop' the Council recommendations from being adopted. The recommendations are in that regard practically automatically adopted. ${ }^{100}$ The difference with a (normal) QMV is that a Council majority actively had to endorse the recommendation. AS regards legal power, the strength of a Member State's dissent, or its possibility to influence the likelihood that the power will be exercised regardless of its consent, is therefore considerably impaired by the reverse QMV procedure.

The recourse to a supranational actor rather than an intergovernmental actor is by itself then important for the allocation of power between the Member States and the Union. The Commission is given a role in the multilateral surveillance procedure as per the Treaty and is present in many situations in the legal framework. So why shed particular light on the issue of reverse QMV? The reverse QMV in this context is stipulated for the decision establishing non-compliance of a Council recommendation in an EIP, which relate to both Euro Area and non-Euro Area Member States, and for imposing financial sanctions in an EIP, which is only possibly for Euro Area Member States. The ability to impose financial sanctions is also a weapon of enforcement. This creates a combination of an enforcement mechanism of which the operator is, by and large, a supranational actor. The reason of this combination is

\footnotetext{
${ }^{99}$ Lenaerts (n 28) 764.

${ }^{100}$ Luca De Lucia, 'The Rationale of Economics and Law in the Aftermath of the Crisis: A Lesson from Michel Foucault' (2016) European Constitutional Law Review 12(3) 445, 448.
} 
visible from the history of enforcement of fiscal discipline. Not only did a lack of enforcement mechanisms exist, but the EDP was a last resort for fiscal discipline and the only enforcement mechanisms for the recommendations based on article 121 TFEU were monitoring and peer pressure. Additionally, the actor empowered to use these enforcement mechanisms were the Council acting by (normal) QMV, which evidently lead to a scenario in which politics ruled rather than upholding the rule of law. ${ }^{101}$

It is quite clear from the systematics of article 121 TFEU that the Council has a central role. It is the Council that adopts the BEPGs, that directs recommended policy action in the event of inconsistency with the BEPGs or when there is a risk to the proper functioning of the EMU. The Commission on the other hand, is set to report to the Council on its surveillance, and in that role also receive information from the Member States (although it may also address warnings to the Member States).

The idea, as discussed above, was that the actor in the economic constitution would be intergovernmental to ensure a high level of State sovereignty. However, when considering secondary law, the reverse QMV has shifted this intra-institutional power balance which in turn shifts the allocation of power between the Member States and the Union. EMU

The last dimension of this legal excel spreadsheet is that of the objectives of the EU's macroeconomic governance. As was argued above, the objectives of economic policy relate to EU competences as they are functional thereto. In other words, these objectives are a part of the EU's competence in macroeconomic policy.

\section{6[a] The main rationale for supranational surveillance}

In terms of Tusseau's theory, the objectives can be perceived as relating to the range of application in that there exists a material criterion that the normative production seeks to attain certain objectives. Wherein the normative production of a power-conferring norm fails to seek those objectives, it would not be within the competences conferred on the actor as per that norm.

In a Commission Communication regarding the MIP, the Commission states that:

The main rationale for a supra-national surveillance mandate builds on the fact that macroeconomic imbalances and economic policies in one country have relevance also for other Member States. This is due not only to the fact that in highly integrated economic areas economic developments in one country spill over to other countries, but also to the fact that, if left unaddressed, macroeconomic imbalances may compromise the proper functioning of the monetary union and the common policies and institutions of the Union, such as the Single Market. ${ }^{102}$

\footnotetext{
101 Ermot Hodson, Governing the Euro Area in good times and bad, (Oxford Scholarship Online 2012), $79 \mathrm{ff}$. 102 European Commission, 'The Macroeconomic Imbalance Procedure Rationale, Process, Application: A Compendium' (Institutional Paper 039, 17.11.2016), 7.
} 
By extension, the proper functioning of the EMU (and the interconnection between the economic developments of the Member States) is identified by the Commission as 'the main rationale' for the Commission's competence of surveillance.

The proper functioning of the EMU is not one of the objectives set by article 119 TFEU. Article 119(3) TFEU identifies the following as 'guiding principles' of the Union and Member State action in economic policy: 'stable prices, sound public finances and monetary conditions and a sustainable balance of payments'. The proper functioning of the EMU is thus not explicitly set as a 'guiding principle' by the Treaty, but it is referred to in article 121(4) TFEU as a reason for EU intervention. By a teleological interpretation then, article 121(4) makes the proper functioning of the EMU a protected interested.

Article 136(1) TFEU also establishes the proper functioning of the EMU as the rationale for the recourse to enhanced cooperation. In that regard, the preamble (para 1) of regulation $1173 / 2011^{103}$, that is the regulation enabling financial sanctions in relation to the SGP, states that: '... [the] budgetary policies [of the Member States] are guided by the need for sound public finances and that their economic policies do not risk jeopardising the proper functioning of economic and monetary union'.

Hence, the preamble places the proper functioning of the EMU and sound public finances on a par, even as only the latter is expressly a guiding principle in economic policy.

Considering that the proper functioning of the EMU is set as a protected interest by the TFEU, that it is used as a rationale for the MIP-regulation and that Regulation 1173/2011 treats the proper functioning of the EMU as a guiding principle, it can be said to be an objective of macroeconomic governance.

\section{6[b] Understanding the Proper Functioning of the EMU as an Overriding Objective}

The expressed basis for the strengthening of Union (especially, Commission) surveillance of macroeconomic policy is, in accordance with the above, the proper functioning of the EMU. That the EMU functions properly can be understood from a concept of solidarity. In a negative sense, the solidary behaviour, heeding to the EU guidance, is in this concept confined to the 'self' but contributes to the interest of the whole ie the EMU. In a positive sense, the Member State would act to benefit the other members of the group, ie the other Member States. As to the motivation behind the solidary behaviour, it could act by a normative solidary motivation, wherein the motivator is the common good of the group. Conversely, factual solidarity exists when the group experiences interdependence and solidarity is therefore implicit. ${ }^{104}$

Translated to the context of macroeconomic governance ${ }^{105}$, the Commission identifies a factual solidarity, namely the spill-over effect for which the economic development in one country is perceived to influence others. But appealing to the proper functioning of the EMU is arguing for normative solidarity, in other words, the EMU is the group of which the Member States forms a part, and its 'proper functioning' is the common good. As to the

\footnotetext{
103 Regulation (EU) No 1173/2011 (n 47).

104 See Borger's concept of solidarity in Vestert Borger, 'How the Debt Crisis Exposes the Development of Solidarity in the Euro Area' (2013) European Constitutional Law Review 9(1) 7, 9-11.

${ }^{105}$ Note that Borger analyses EU economic governance in light of the solidarity concept he has created, but does not develop on the MIP-regulation.
} 
behaviour of the Member States, heeding to the EU guidance is mainly confined to the self, ie exhibits negative solidarity. The Member States are to pursue its own fiscal soundness (follow the recommended policy action) which will ensure solidarity, ie that the EMU functions properly (normative) and to avoid adverse spill-over effect (factual).

Contrariwise to the concept of solidarity, EU has been described as a (rather maleficent) besserwisser, exercising authoritarian power by use of an emergency law rationale. In this regard, Somek has paralleled (ironically): '[a]s is well known, intoxicated persons are not only severely impaired in their driving skills, but also incapable of recognising their impairment'. ${ }^{106}$ In other words, the author perceives the Union to reason its economic governance in terms of being better equipped than the Member States to make judgements. Translated into the macroeconomic framework, Member States experiencing economic distress (the intoxicated) are, seemingly evidently, not equipped with the financial intellect to regard its own impairment, thus in need of the (sober) EU (unwanted, but necessary) guidance. The EU economic 'permanent and systematic interference with national competence' is regarded by Somek as an expression of authoritarianism, albeit not of outright repression. ${ }^{107}$ The proper functioning of the EMU is in this view a rationale invoked, and its nature determined, by the Union in order to ex post explain that it had the competence to adopt the measures.

Considering that objectives are functional to competencies, and not the other way around, the EU does not have the competences needed to attain the objective, instead, by the limit of the principle of conferral, only the competences which have been conferred may be used to attain the objective. This entail that, even as for example the use of financial sanctions may dissuade action which would risk the proper functioning of the EMU (ie attain the objective), it could only be used if the Union has been conferred such a competence. However, as stipulated in article 121(4) TFEU, the Union is conferred a competence to preserve the smooth functioning of the EMU. Thus, there is no clear cut between the objective and the competence to preserve proper functioning of the EMU.

Whether or not one categorizes this as an objective or as a competence, the Member States have given up their power to autonomously set the objectives of economic policy. More and more, the secondary law adopted by the Union hammers the functionality of the EMU as its justification and goal, making it now not only an abstract vision, but a form of power that is difficult to question. On that note, 'a huge simplification of values has taken place, since certain economic objectives must prevail over all other values'. ${ }^{108}$ The implementation of this, now, overriding objective is insensitive to political bargaining due to the reverse QMV, in fact then decided by the Commission. Moreover, as the framework of economic policy is now moving towards evaluation-oriented governance, in that steering the actions of Member States rest on the evaluation of their economic performance rather than their compliance with certain norms ${ }^{109}$, the importance of this overriding objective is further strengthened. The Union may evaluate the economic performance of the Member State in light of the overriding objective.

\footnotetext{
106 Somek (n 5) 354.

107 ibid $340 \mathrm{ff}$.

108 De Lucia (n 100) 455.

109 ibid.
} 
On the other hand, the constitutional scope of the framework only allows the Union to try to coordinate policies, albeit through enforcement measures in the direst circumstances, in light of the interest of the Union (that is, the smooth functioning of the EMU), but the Union cannot implement policies on a supranational level.

\section{A FEDERAL PATTERN}

To reiterate, the purpose of the article is to discern a pattern of federalism and to offer an explanation as to why, on a broader note of EU constitutionalism, this development has mostly been characterized by centralization.

\subsection{SNAPSHOT OF THE ECONOMIC CONSTITUTION: THE INSTITUTIONAL PRACTICE AND ITS DIRECTION}

A first conclusion on the presentation above and comparing the pre- and post-crisis exercises of competence is that the Union has ventured into a new area - that is, macroeconomic governance. The direction of institutional practices has in that regarded meant an expansion of the substantive areas in which the Union exercises its competence. Macroeconomic policy was in my view foreseen as an area of Union competence as per the Treaty provisions, but the MIP-regulation is the first legislative act directly aimed at governing macroeconomic policy.

Secondly, the use of soft law, namely recommendations initiated by the Commission and adopted by the Council, is also inherent in primary law. In my opinion, the constitutional frame allows for the level of detail, what could be perceived as the level of intrusiveness, of the recommendations to increase. ${ }^{110}$ The reason thereto is that article 121(4) TFEU does not put a cap on the level of detail. On the other hand, the underlying principle behind the allocation of power between the Union and the Member States in this regard is to protect state sovereignty in matters requiring democratic legitimacy and control. On that note, even as the recommendations may become increasingly detailed, recommendations under the MIP or the EIP may only reason to protect the proper functioning of the EMU rather than to directly relate to a Union stance on redistributive justice. As was articulated by Hinarejos, the fuller surveillance model of future integration would entail specific recommended action which the Union may enforce. ${ }^{111}$ I agree with her that we are in the initial phase of this model. Because I argue that there is no cap on the level of detail of the recommended corrective action, which is enforceable through financial sanctions, the possibilities of reaching that model completely are in theory existing.

On a broader note, what can be said on the nature of macroeconomic coordination? Tusseau highlighted the vulnerability of using vague language, which would make redundant a semantic interpretation of 'providing arrangements' as article 2(3) TFEU foresees. Looking at the normative production of article 121 TFEU, in particular the CSRs and the MIPregulation, I argue that the Union is acting on a spectrum between providing arrangements and legislating economic policy. On the one hand, it is not merely providing arrangements

\footnotetext{
${ }^{110}$ Note again, that this considers only Tusseay's theory of power-conferring norms and not, for example, the principles of subsidiarity and proportionality.

${ }^{111}$ See Hinarejos (n 8) $181 \mathrm{ff}$.
} 
as the secondary legislation enables enforcement of recommended policy action. In that regard, the Union will require policy response to decrease an imbalance which is defined in part in relation to the proper functioning of the EMU. That means that the Union has the possibility to enforce their view on sound fiscal and economic policies in light of the interests of the Union. On the other hand, such policy interference is only possible in a particular situation, that is under the existence of macroeconomic imbalances. This limitation to the Union's possibility to act is clearly very different from the sovereign nation state's unlimited possibility to pursue its own economic agenda. However, as it is the Union who establishes the existence of an excessive imbalance, for which the definition is broad and sensitive to discretionary evaluation, the centralization of legal power is theoretically strong. In other words, there is a theoretical distribution of power characterized as more federal-like in the sense that the macroeconomic power is centralized to the Union's intergovernmental and supranational institutions. If this possibility is seized and whether it will be met by obedience by the Member States or if they will challenge the exercise of Union power is a question for the future.

On the analysis presented in chapter 3, I argue that the direction of the Union's practices is in theory characterized by general deeper integration on substantive macroeconomic issues but differentiated integration in relation to enforcement. By theory I refer to the competences exercised by secondary law which should be opposed to the practice in terms of whether and how the Union decides to make use of those competences. The direction of the practices in the sense of legislation but not necessarily implementation is moving towards hard enforcement. This is evidenced by the interplay between hard and soft law, which entails that soft law instruments (recommendations) are enforceable by use of, or at least threat of, financial sanctions (hard law). Additionally, the increased importance of the role of the Commission results in a step towards Member State accountability for compliance with the EU macroeconomic framework. However, as I have already mentioned, the Commission has consistently established the existence of macroeconomic imbalances and even those of excessive nature, but the Commission has never recommended opening an EIP. Additionally, the research shows that adherence to the CSRs is seldom high, mostly scoring as 'limited' or 'some' progress (towards compliance).

\subsection{THE EVOLUTIONARY ECONOMIC CONSTITUTION - UNDERLYING CAUSES}

The second question posed by de Búrca was why integration is strengthened despite so much resistance. The deepening of integration has been seen in most policy areas in the history of the EU project, and I am optimistic that I have shown that these broad brushstrokes can also be used to paint the picture of the governance of EU macroeconomic policy. As for the reasons the centralization is accepted, in the sense that the frameworks are adopted, I believe that there are many possible answers which lie outside the frame of the article. However, I will propose some explanations based on what has been discussed above.

I would argue that one possible culprit in this plot is the vagueness of the expressed limits of the competence in economic policy. The scholarly division as to how to interpret coordinating competence as illuminated above underlines this ambiguity. It could be argued that the Union needed to fill in the blanks by its institutional practices. The political background of this is of course constructed mainly on the bricks of the economic crisis. In 
line with the argument made by Somek, the crisis could accentuate the already underlying modal indifference of trust in the sense that the Union could point to the economic distress of the Member States as a need for the Union's presumed wisdom and guidance. Italy's disobedience in regard to their 2019 draft budget could be perceived as a sign of the cracks in the trust relationship. Conversely, the increase of EU-scepticism and even EU-hostility would be reasons for an opposite development. Perhaps for the Member States which have received financial assistance in particular, foregoing guidance to appease public opinion might be difficult. In any event, the deliberate vagueness of the Treaty provisions as to the nature of the Union's competence in economic policy could be one reason further integration was possible.

Further in relation to Somek's trust theory, the reverse direction of control entails that a situation of 'ask for forgiveness rather than permission' is created, in the sense that legislation as a rule is adopted on the basis of a QMV (in accordance with the OLP) and that it can only thereafter be challenged by the Member States in an annulment proceeding as set out in article 263 TFEU. The CSRs cannot be challenged in this way, which is expressly stated in the same article, but the MIP-regulation and the Enforcement-regulation could be challenged because they are legislative acts. However, no such actions have been initiated by the Member States. Even if it would, according to Somek, the only viable control is democratic control. In the macroeconomic framework, no such control exists. This might explain why the people affected by the measures, that is the Union citizens, are increasingly turning to EU-sceptic and EU-hostile national parliamentary parties. As seen in the case of Italy, such parties are the counter-pole to the EU institutions, challenging the measures adopted. On the other hand, the interests of the Member States are supposed to be represented by the Council, which is the actor adopting the CSRs and any decision under the EIP, including sanctions. In that view, the level of delegation, and by extension the level of asymmetry in the trust relationship, is lower and less susceptible to the trust trap. But the Member States' possibilities to influence those decisions are weakened by the introduction of the reverse QMV. The element of the modal indifference of trust, namely of reverse direction of control, in combination with the weakening of the Member States' influence in the Council may be another reason why the strengthening of the framework has taken place.

As one is discussing the strengthening of the macroeconomic framework, it is important to keep in mind that this policy area is still one of the most de-centralized competence areas of the Union. Even as legal power has become more centralized, most power remains within the competences of the Member States. The substantive macroeconomic policies of the Member States are diverse and cannot be said to inhabit a strong harmonization. It seems likely that the democratic dimension is the biggest brake pad in the development of the EU macroeconomic framework. The need thereof is also recognized by the Commission. ${ }^{112}$

The Commission has argued that the economic crisis revealed that the realities of fiscal policy interconnect with the realities of macroeconomics. On that basis, it argued that macroeconomic policy also needed to be centrally governed to some extent. Venturing into financial and numerical fiscal policy rules could therefore be perceived as the first step of EU

112 European Commission, COM (2012) 777 final (n 22) 11. 
economic governance. Subsequently, macroeconomic governance followed by that logic. ${ }^{113}$ Another reason for the centralization of macroeconomic governance may therefore be that the legal separation of these policy areas did not mirror the economic reality, that is interconnection therebetween. Considering the growing importance of the objective relating to the proper functioning of the EMU, that interconnectivity becomes further influential. If fiscal prudence was the overriding objective, the interconnectivity would be less important because fiscal prudency can be evaluated on an intra-state rather than inter-state level. The same is not possible for the proper functioning of the EMU, as the EMU by nature requires an inter-state evaluation. Focusing rather on an inter-state than an intra-state objective may also give rise to centralization since the issue focuses more on the group than the individual. The recognition of the interconnection between the policy areas, in combination with the interconnection between the Member States, resulting in the growing importance of the proper functioning of the EMU, may therefore be another reason for centralization of EU legal power in macroeconomics.

\section{PREDICTIONS: LOOKING AHEAD}

My prediction is that the most telling tale of EU economic governance in the future will star Italy, as it is currently the most vocal in its official resistance to Union intervention in regard to its national budget. Whether the Commission decides to recommend Union action, either in launching the EDP or the EIP, will speak of the willingness to use the enforcement mechanisms that are available. If it does not make use of those mechanisms, it seems likely that the framework will suffer the same fate as the BEPG and SGP did in the 90's and early $2000{ }^{114}{ }^{114}$ in the sense that the perception that accountability exists for the Member State would probably decrease. Just as the Union lacked bite in relation to those earlier instruments, so would it seem to do now. The aspect that speak against such a development is the post-crisis situation which creates a different context than was the situation for the SGP and BEPGs pre-crisis. On the other hand, the Union has faced backlash over the austerity measures. Even as the austerity measures regard the financial assistance, the discourse could taint the trust of EU fiscal and economic governance by making the Union less inclined to interfere. That might especially be the case as the Union is experiencing growing EU-scepticism and even EU-hostility. As regards Italy, the Italian government's intention is to launch socio-economic reforms to tackle the dire economic situation in the country. ${ }^{115}$ That would mean increased public spending, which is what the Commission critiqued in its opinion on Italy's DBP in light of the debt and deficit situation in the country. It is beyond doubt that the Union is within its legal mandate to launch an EDP against Italy. However, the danger emerges if the Union fails to effectively communicate to the EU citizens the reasons it reasons these reforms should not take place. In particular, the Union institutions must appeal to the interests of those citizens rather than the interests of the Union, or the trust in the EU project could be threatened.

${ }^{113}$ European Commission, 'The Macroeconomic Imbalance Procedure Rationale, Process, Application: A Compendium' (n 102) 18.

114 See Hodson (n 101).

115 See eg Gavin Jones, 'Italy government approves flagship welfare reforms' Reuters (17 january 2019)

$<$ https://www.reuters.com/article/us-italy-politics/italy-government-approves-flagship-welfare-reformsidUSKCN1PB1TK> accessed 20 June 2019. 